\title{
Letter to the Editor: Detection of Cystic Fibrosis Protein by Isoelectric Focusing of Serum
}

\author{
G. WALTER TULLY, ${ }^{(14)}$ GERALD B. NEVIN, IAN R. YOUNG, AND NORMAN C. NEVIN \\ Department of Life Sciences, Ulster Polytechnic, Newtownabbey, Northern Ireland and Department of Medical \\ Genetics (N. C. N.) The Queen's University of Belfast, Belfast, Northern Ireland
}

Several cystic fibrosis (CF) research groups in both North America and Europe have independently attempted to reproduce the isoelectric focusing work of Wilson et al. (11) with widely varying results. Some have been completely unable to detect a $C F$ protein $(6,7)$; one group has observed a distinctive protein using a combination of electrofocusing and electrophoresis (1) and only one other group has claimed any success for the electrofocusing technique (5). However, the results obtained by this last group would indicate that the frequency of occurrence of the cystic fibrosis protein (CFP) is such that "the technique is not a diagnostic test", a conclusion which is disputed by Wilson and Fudenberg (10). Moreover, Scholey et al. (5) reported that detection of the extra protein band in CF sera by visual observation was difficult and required color photography to eliminate background interference and permit a proper interpretation of the electropherograms.

The protocol that we employed with the LKB Multiphor electrofocusing apparatus was that of Wilson et al. (9), although fixing and staining of the polyacrylamide gels was performed in a boiling water bath for 30 min (8). In 10 of 11 sera from patients with CF, the CFP band was directly identified by each of two independent observers and in the sera from nine obligate heterozygote individuals, the CFP band was noted in seven and eight instances by each observer, respectively. In sera from 26 normal control individuals, the CFP band was observed in two instances. Our electrofocusing results would, therefore, support the view that the CFP band is indeed directly indentifiable in both CF heterozygote and homozygote sera without recourse to photographic image enhancement and that its frequency of occurrence is similar to that reported previously (11).

It should be stressed that the visual appearance of the banding pattern of the final few $\mathrm{mm}$ of an individual lane can vary somewhat between CFP positive specimens. In most CF homozygote and heterozygote samples, one can observe a sharp frontal edge closely followed by the distinctive CFP band that is clearly resolved from those proteins of lower isoelectric point. However, in some specimens, this classic picture is less distinct, but is still sufficiently clear to allow a positive designation. It is possible that the difference in frequency of the CFP band reported by the various groups of workers may be partially explicable in terms of the criteria used to assign a positive result. In this context, the obligatory use of positive and negative controls should assist the interpretation of individual specimens, rather than simply comparing one unknown lane with another. To this end, we are investigating the production of lyophilized control sera and their possible use as an interpretative aid between laboratories.

In conclusion, our preliminary results would tend to support the contention that the CFP is a useful marker for the CF gene, although we must stress that close attention to various aspects of experimental detail is necessary to obtain meaningful data. It is, however, interesting to note that we have confirmed the findings of Wilson et al. (11), albeit in a single instance, that a CF patient may consistently prove to be negative for the CFP. This finding, if verified by more complete studies, would indicate that there may be a subpopulation of CF patients who represent a separate phenotype. This concept of genetic heterogeneity for $C F$ has already been suggested as a consequence of atypical intracellular metachromatic response of cultured skin fibroblasts (2-4). Further work still needs to be undertaken to determine the possible relationship between the CFP and the pathogenesis of CF. Although the number of specimens that we have investigated to date is small, a more exhaustive study may confirm the value of isoelectric focusing as a diagnostic technique for individuals who carry the $\mathrm{CF}$ gene.

\section{REFERENCES AND NOTES}

1. Altland, K., Schmidt, S. R., Kaiser, G., and Knoche, W.: Demonstration of a factor in the serum of homozygotes and heterozygotes for cystic fibrosis by a nonbiological technique. Humangenetik, 28: 207 (1975)

2. Bearn. A. G.: Cell culture in inherited disease-with some notes on genetic heterogeneity. N. Engl. J. Med., 286: 764 (1972)

3. Danes, B. S., Hodson, M. E., and Batten. J.: Cystic fibrosis: evidence for a genetic compound from a family study in cell culture. Clin. Genet., I1: 83 (1977)

4. Polley, M. J., and Bearn, A. G.: Cystic fibrosis: current concepts. J. Med. Genet., 11: 249 (1974)

5. Scholey, J., Applegarth, D. A., Davidson, A. G. F., and Wong, L. T. K.: Letter to the editor: detection of cystic fibrosis protein by electrofocusing. Pediatr. Res., I2: 800 (1978)

6. Smith. Q. T. Hamilton, M. J., and Shapiro, B. L.: Letter to the editor. Pediatr. Res., 10: 999 (1976)

7. Thomas, J. M., Merritt, A. D., and Hodes, M. E.: Electrophoretic analysis of serum proteins in cystic fibrosis. Pediatr. Res., 11: 1148 (1977)

8. Wilson, G. B.: Personal communication, September, 1978

9. Wilson, G. B., Arnaud, P., and Fudenberg, H. H.: Improved method for the detection of cystic fibrosis protein in serum using the LKB Multiphor electrofocusing apparatus. Pediatr. Res., 11: 986 (1977)

10. Wilson. G. B., and Fudenberg. H. H.: Letter to the editor: is cystic fibrosis protein a diagnostic marker for individuals who harbor the defective gene? Pediatr. Res., 12: 801 (1978)

11. Wilson, G. B., Fudenberg, H. H., and Jahn, T. L.: Studies on cystic fibrosis using isoelectric focusing. I. An assay for detection of cystic fibrosis homozygotes and heterozygote carriers from serum. Pediatr. Res., 9: 635 (1975)

12. The authors thank Dr. A. O. Redmond, Consultant Pediatrician, Royal Belfast Hospital for Sick Children, for the provision of clinical specimens.

13. This research was supported by the British Cystic Fibrosis Research Trust and the Ulster Polytechnic Research Fund.

14. Requests for reprints should be addressed to: G. W. Tully, M.Sc., Department of Life Sciences, Ulster Polytechnic, Newtownabbey, Co. Antrim, Northern Ireland, BT37 OQB.

15. Received for publication January 24, 1979.

16. Accepted for publication March 22, 1979. 